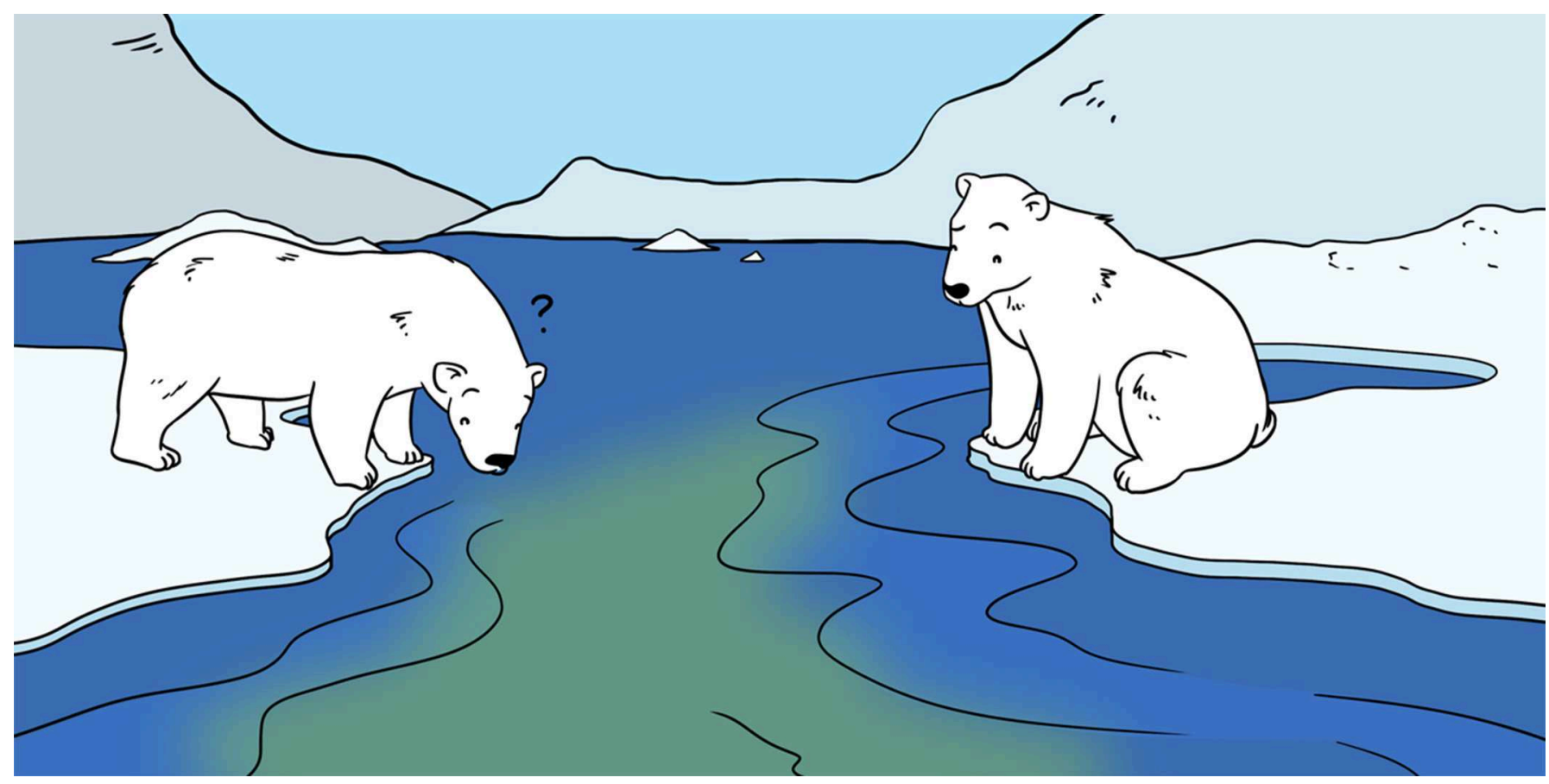

\title{
THE CARBON STORY OF A MELTING ARCTIC
}

\section{Johan C. Faust ${ }^{1^{*}}$, Christian März ${ }^{1}$ and Sian F. Henley ${ }^{2}$}

${ }^{1}$ School of Earth and Environment, University of Leeds, Leeds, United Kingdom

${ }^{2}$ School of GeoSciences, University of Edinburgh, Edinburgh, United Kingdom

YOUNG REVIEWERS:

CLAIRE

AGE: 15

JULIETTE

AGE: 15
Large parts of the far north of our planet, the Arctic, were permanently covered with ice for thousands of years, but this is now changing. By burning fossil fuels like coal and oil, we rapidly return carbon, stored for millions of years in the Earth's crust, back into the atmosphere. This increases the carbon dioxide $\left(\mathrm{CO}_{2}\right)$ concentration in the atmosphere and causes Earth's surface temperature to rise. Warmer temperatures and melting sea ice and glaciers are changing the Arctic environment. In a few decades, the North Pole could be ice-free for the first time in human history. A warming Arctic will have global consequences, through higher sea levels, changes in climate and precipitation patterns, and loss of fish, birds, and marine mammals. In this article, we discuss how large changes in the Arctic environment may affect the entire planet.

\section{POLAR MELTDOWN IN A WARMING WORLD}

The Arctic and Antarctic are the Earth's north and south polar regions. They stand out on our planet as hostile, icy deserts with average 
Figure 1

(A) The amount of Arctic sea ice per year (in September) from 1935 to 2018. From 1935 to 1979 (dotted blue line) the ice extent was estimated from atmospheric temperature measurements [1] From 1979 onwards (solid blue line), the ice extent was measured directly by satellites. You can see that since 1970 almost $40 \%$ of the Arctic sea ice has melted. (B) The area of all the yellow countries (Portugal, Spain, France, Italy, Belgium, the Netherlands, United Kingdom, Germany, and Norway) is about 2.4 million square kilometers - the same area that has been lost from Arctic sea ice melting over the past 30 years.

\section{CLIMATE}

Changes in air temperature, wind speed and direction, precipitation and cloud cover in a time range of hours, days, and weeks is what we call "weather." Climate is the average weather over a longer period of time (decades to millions of years) at a certain location. It is not possible to see, feel, or

measure climate.

\section{HABITAT}

A habitat is the environment where a plant or animal normally lives and grows.

\section{NUTRIENTS}

A nutrient is a chemical substance required by organisms to live.
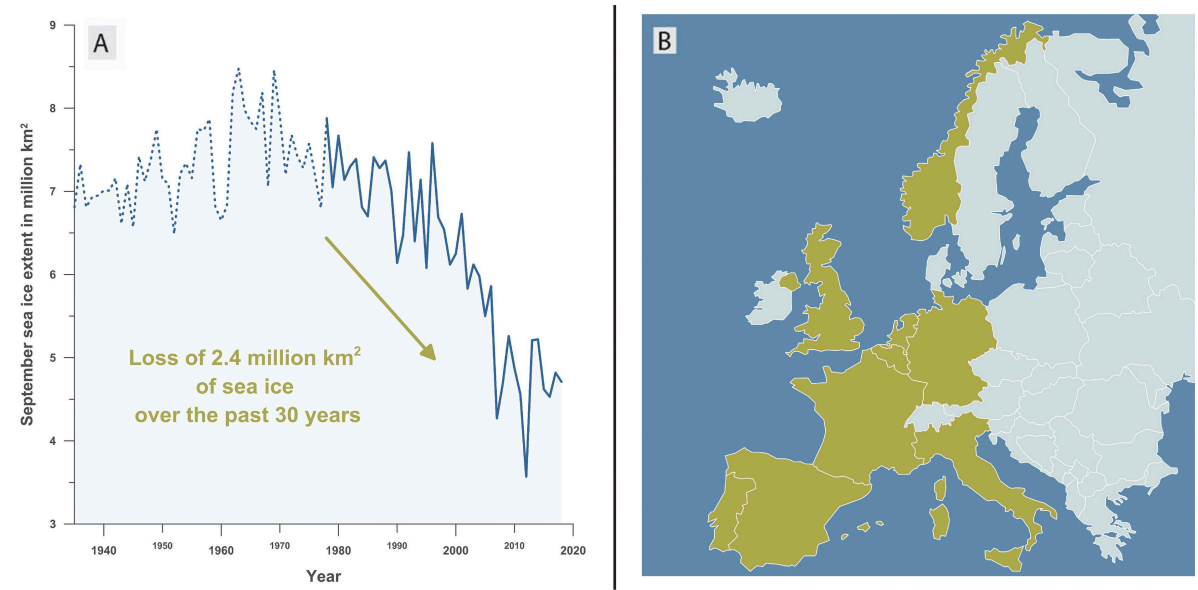

Figure 1

winter temperatures of $-40^{\circ} \mathrm{C}$ at the North Pole and $-60^{\circ} \mathrm{C}$ at the South Pole. During winter, the polar regions experience months of complete darkness, while during summer, the sun never sets. Although both polar regions are cold and receive the same amounts of sunlight during the year, there is a fundamental difference between the Arctic and Antarctic.

Antarctica is a continent covered by ice and surrounded by the Southern Ocean. The Arctic is mostly an ocean, covered by sea ice and surrounded by three continents: North America, Asia, and Europe. Current climate change is raising Arctic air and ocean temperatures, causing the area covered by sea ice to shrink. During the past 30 years, about 2.4 million square kilometers of Arctic sea ice have melted-this is equivalent to an area the size of western Europe (Figure 1). Although the Arctic is an ocean, the sea ice acts like a land surface, creating an important habitat for many animals like seals and polar bears (Figure 2). Since the 1970s, almost $40 \%$ of the total Arctic sea ice has disappeared, and the large and small animals that live on that ice are losing their homes and must find other places to live, before they become extinct. On the other hand, certain fish species and algae known as phytoplankton can now thrive in the newly ice-free areas (Figure 2).

\section{CARBON DIOXIDE UPTAKE BY PHYTOPLANKTON}

Current climate change is causing Arctic air temperatures to increase about twice as fast as average temperatures over the rest of the world [2]. The rising temperatures in the Arctic region will not only melt sea ice, but will also cause higher amounts of freshwater from melting glaciers to flow into the Arctic Ocean. This freshwater can be rich in nutrients that provide essential fuel for phytoplankton growth. Phytoplankton are very important; like plants on land these organisms 
Figure 2

Climate change causes sea ice to melt,

transforming the Arctic from an icy desert into an open ocean. Polar bears and seals may lose their habitats, phytoplankton growth may increase and fuel the Arctic food web, which may lead to higher carbon burial rates and possibly decrease the amount of $\mathrm{CO}_{2}$ in the atmosphere.

\section{FOOD CHAIN}

Food chains begin with plant-life which converts solar energy to food by photosynthesis. Plant-eating animals get eaten by flesh-eating animals. Smaller flesh-eating animals are eaten by larger flesh-eating animals. For example, carrots are eaten by rabbits, rabbits are eaten by foxes, and foxes are eaten by bears.

\section{CARBON}

Carbon is a chemical element with the symbol $\mathrm{C}$ and one of the most abundant elements on the planet and in the universe. In pure form, carbon exists as graphite or diamond. It exists in all living organisms and is an important part of coal and oil. When carbon is burned, it reacts with oxygen $(\mathrm{O})$ and forms a gas, carbon dioxide $\left(\mathrm{CO}_{2}\right)$.

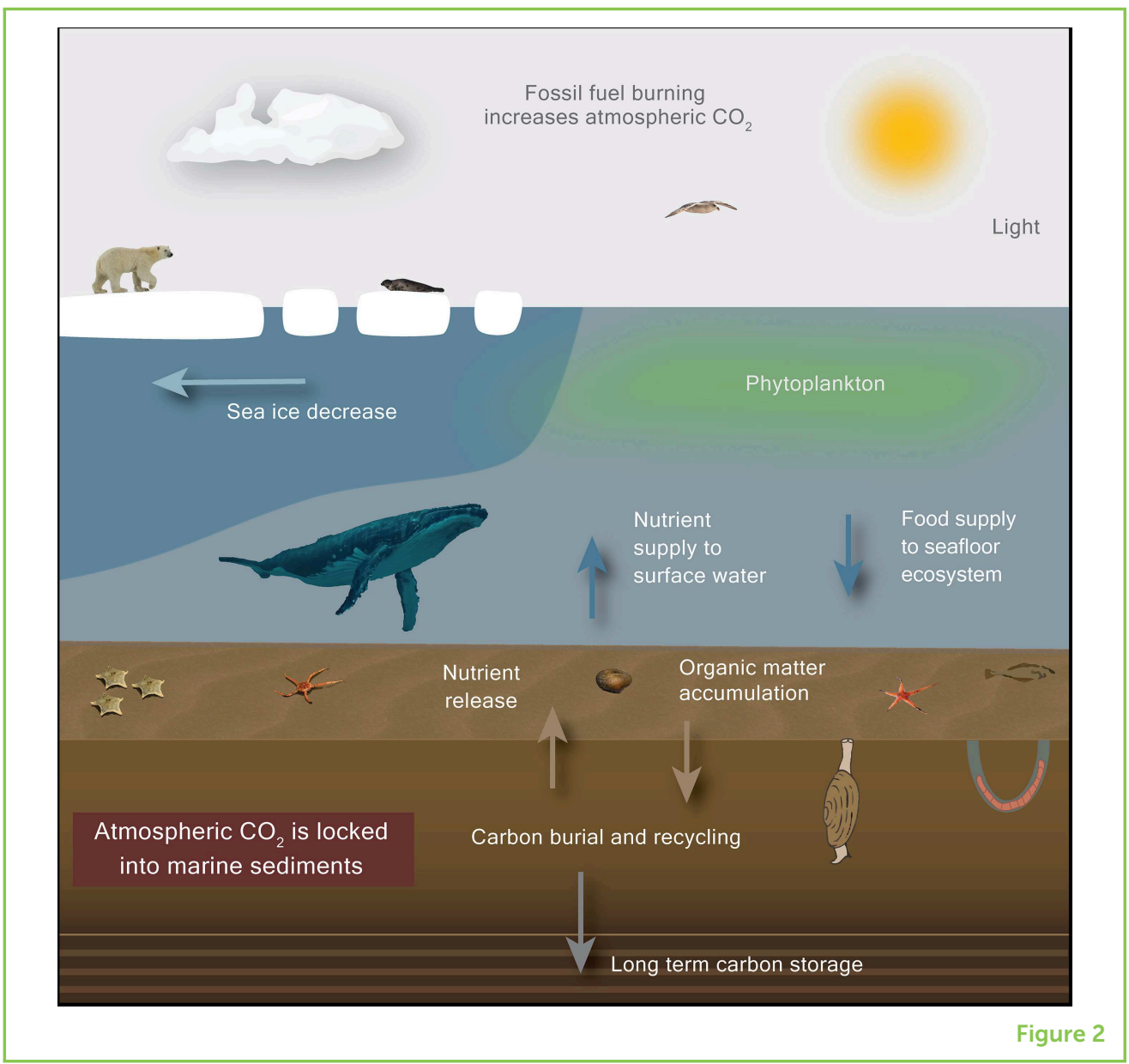

are at the bottom of the food chain and therefore they are the foundation for almost any life in the ocean. But phytoplankton are more than just a food source for small and large animals like shrimp and fish. Like all plants, phytoplankton take up carbon dioxide $\left(\mathrm{CO}_{2}\right)$ from the atmosphere and, using the sun's energy, break it down into carbon $(\mathrm{C})$ and oxygen $\left(\mathrm{O}_{2}\right)$. The oxygen is released back into the air or water. The carbon is used by phytoplankton to build their tissues. Therefore, plants have the unique ability to transform $\mathrm{CO}_{2}$ from the atmosphere into other compounds during photosynthesis, and you will soon see why this is important.

\section{THE CARBON CYCLE}

Of the 118 known chemical elements, only a small number can be found in living organisms. Astonishingly, the immense complexity of life on Earth is made up almost entirely of only four elements: carbon $(C)$, hydrogen $(H)$, oxygen $(O)$, and nitrogen $(N)$. For example, about $99 \%$ of your body consists of these four elements! If organisms like humans or phytoplankton die, their bodies get broken down into $\mathrm{C}, \mathrm{H}$, $\mathrm{O}$, and $\mathrm{N}$. During this process, the carbon is transformed back to $\mathrm{CO}_{2}$. As we said, phytoplankton can consume $\mathrm{CO}_{2}$ during photosynthesis, 
Figure 3

Monthly mean atmospheric $\mathrm{CO}_{2}$ concentration in parts per million (ppm; 400 $\mathrm{ppm}=0.04 \%$ ) measured at Mauna Loa Observatory in Hawaii, from 1958 until today. The gradual increase in $\mathrm{CO}_{2}$ is caused by burning fossil fuels. The short term up-and-down variations are mainly caused by seasonal changes in the uptake and release of $\mathrm{CO}_{2}$ by plant growth in the northern hemisphere. Data are from: Dr. Pieter Tans, NOAA/ESRL

(www.esrl.noaa.gov/gmd/ ccgg/trends/) and Dr. Ralph Keeling, Scripps Institution of Oceanography (scrippsco2.ucsd.edu/)

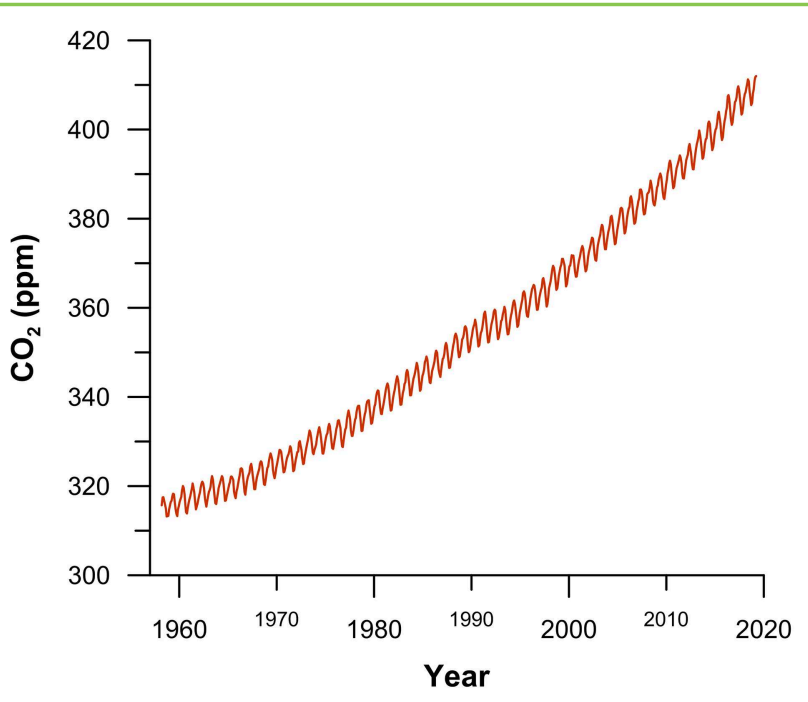

Figure 3

which decreases the amount of $\mathrm{CO}_{2}$ in the atmosphere. But, when the phytoplankton die and decompose, the same amount of $\mathrm{CO}_{2}$ they took up is released back into the atmosphere. This does not just happen with phytoplankton-when the trees in the northern hemisphere lose their leaves in autumn, the global $\mathrm{CO}_{2}$ concentration rises, and in spring, when new leaves grow back, global $\mathrm{CO}_{2}$ concentration drops again (Figure 3). So, in nature, $\mathrm{CO}_{2}$ is constantly being removed from the atmosphere and added back to the atmosphere. This is called the biological carbon cycle. If the production and consumption of carbon are in equilibrium, the $\mathrm{CO}_{2}$ concentration in the atmosphere should be constant. However, large environmental changes and human activities can upset this equilibrium. For example, if a tropical forest is replaced by a desert with very few plants, the carbon stored in the forest will be released into the atmosphere and not taken back up.

Despite what you may have heard on the news, $\mathrm{CO}_{2}$ is not always a bad guy! In fact, $\mathrm{CO}_{2}$ is essential for regulating the temperature of our planet. Without greenhouse gases like $\mathrm{CO}_{2}$, life on Earth would not exist because Earth's average temperature would drop to $-18^{\circ} \mathrm{C}$ which is too cold for living things [3]. But, by burning fossil fuels, we quickly release large amounts of $\mathrm{CO}_{2}$ into the atmosphere. Because this $\mathrm{CO}_{2}$ cannot be taken back up as quickly as it is released by burning fossil fuels, there is an imbalance in the carbon cycle and a rise in the amount of $\mathrm{CO}_{2}$ in the atmosphere (Figure 3). This imbalance is what drives the rapid global climate change that is causing such problems today. To better understand and predict Earth's future climate, it is very important to understand and identify the ways that $\mathrm{CO}_{2}$ is released into the atmosphere and the ways it is removed from the atmosphere. As the Arctic changes from an icy desert into an open ocean, we need to understand how this huge environmental change in the Arctic will influence the global carbon cycle. 


\section{CARBON BURIAL IN ARCTIC MARINE SEDIMENTS}

The main way to reduce the amount of $\mathrm{CO}_{2}$ in the atmosphere for a long time is to store carbon in Earth's sediments-where it was stored until it was released by burning fossil fuels. This storage happens naturally when living things, like phytoplankton, die and sink down to the sediment on the seafloor (Figure 2). The dead organisms that reach the seafloor are a food source for other organisms living there, like starfish, worms, and bacteria. These animals consume the organic matter and break it down into its elements (Figure 2). Most of the carbon and the other elements released during this process stay in the water and feed other organisms, but a small amount of carbon gets buried and is stored in the ocean sediments. Although the amount of carbon that gets trapped this way is small [4], once it is buried it cannot go back into the atmosphere. Because oceans cover more than $70 \%$ of the Earth's surface, this process has a huge impact on the carbon cycle. We call this trapping process carbon burial, and it is a very important mechanism that has regulated $\mathrm{CO}_{2}$ concentrations in the atmosphere, and therefore Earth's temperature, for billions of years. The processes that control carbon burial are still not very well-understood, and scientists are working to understand them better.

\section{WILL A WARMING ARCTIC INCREASE CARBON BURIAL IN ARCTIC SHELF SEDIMENTS?}

The Arctic Ocean is very deep in some areas, almost $5.5 \mathrm{~km}$, but it is shallower (only $50-340 \mathrm{~m}$ ) near surrounding land. These much shallower parts represent about half of the Arctic Ocean. Lots of phytoplankton grow in these shallow areas during summer, when there are $24 \mathrm{~h}$ of daylight. The growth of phytoplankton supports rich and diverse ecosystems in the ocean, on the ice, and at the seafloor, so these Arctic shelf regions are especially important for the cycling and burial of carbon. One hypothesis is that, if there are enough nutrients to support the growth of phytoplankton, the warming of the Arctic could possibly lead to large blooms of phytoplankton, which could result in more $\mathrm{CO}_{2}$ being taken from the atmosphere and stored in the Arctic Ocean seafloor (Figure 2). But, the environmental responses to changes in sea ice are complex, variable, and not well-understood. For example, satellite observations have shown that, in some areas of the Arctic, shorter sea ice seasons and therefore longer growing seasons increased the total amount of phytoplankton, but in other areas, sea ice reductions seemed to affect water circulation, which changed nutrient availability and decreased the amount of phytoplankton.

Because $\mathrm{CO}_{2}$ in the atmosphere is evenly distributed around the world, changes in the Arctic carbon cycle will affect the entire planet. So, changes in the amount of carbon burial in the Arctic are also important for the whole world. Much more research is needed to understand the critically important role of the Arctic Ocean carbon cycle in the 
global climate. Scientists around the world are involved in this huge research effort. As a recent addition to this international research effort, the Changing Arctic Ocean Seafloor (ChAOS) project is a major UK research collaboration investigating how seafloor ecosystems are affected by Arctic warming and sea ice losses, and how these changes can affect carbon burial now and in the future.

ChAOS scientists are trying to find answers to questions, such as: how will the animals and microorganisms living on the seafloor respond to changes in sea ice and ocean processes? Will a decline in sea ice increase the supply of food to seafloor ecosystems? How will seafloor organisms change the way they recycle nutrients and carbon between the seafloor and the ocean? And, how will the amount of carbon stored in seafloor sediments change as global climate change continues? The Arctic is a very remote and hostile realm, into which only very few people will ever venture. By burning fossil fuels, humans have started a huge environmental change in a region where only a few people permanently live. We can expect that major changes in the Arctic ecosystem, and effects on carbon burial, will intensify as our planet heats up further. Since changes in the polar regions affect every one of us, no matter where we live, it is crucial to answer the fundamental scientific questions, so we can better understand the effects of these immense environmental changes on human civilization.

\section{FUNDING}

This work resulted from the ChAOS project (NE/P006493/1), part of the Changing Arctic Ocean programme, jointly funded by the UKRI Natural Environment Research Council (NERC) and the German Federal Ministry of Education and Research (BMBF).

\section{REFERENCES}

1. Connolly, R., Connolly, M., and Soon, W. 2017. Re-calibration of Arctic sea ice extent datasets using Arctic surface air temperature records. Hydrol. Sci. J. 62:1317-40. doi: 10.1080/02626667.2017.1324974

2. Screen, J. A., and Simmonds, I. 2010. The central role of diminishing sea ice in recent Arctic temperature amplification. Nature 464:1334-7 doi: 10.1038/nature09051

3. Lacis, A. A., Schmidt, G. A., Rind, D., and Ruedy, R. A. 2010. Atmospheric $\mathrm{CO}_{2}$ : principal control knob governing Earth's temperature. Science 330:356-9. doi: 10.1126/science.1190653

4. Berger, W. H., Smetacek, V. S., and Wefer, G. 1989. Ocean productivity and paleoproductivity-an overview. Life. Sci. R 44:1-34.

SUBMITTED: 07 June 2019; ACCEPTED: 19 November 2019; PUBLISHED ONLINE: 03 December 2019. 
EDITED BY: Noemie Ott, Swiss Federal Laboratories for Materials Science and Technology, Switzerland

CITATION: Faust JC, März C and Henley SF (2019) The Carbon Story of a Melting Arctic. Front. Young Minds 7:136. doi: 10.3389/frym.2019.00136

CONFLICT OF INTEREST: The authors declare that the research was conducted in the absence of any commercial or financial relationships that could be construed as a potential conflict of interest.

COPYRIGHT @ 2019 Faust, März and Henley. This is an open-access article distributed under the terms of the Creative Commons Attribution License (CC BY). The use, distribution or reproduction in other forums is permitted, provided the original author(s) and the copyright owner(s) are credited and that the original publication in this journal is cited, in accordance with accepted academic practice. No use, distribution or reproduction is permitted which does not comply with these terms.

\section{YOUNG REVIEWERS}

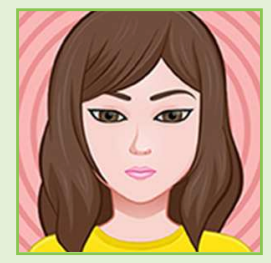

\section{CLAIRE, AGE: 15}

I go to high school in New York, where I spend my time writing poetry and playing the piano.

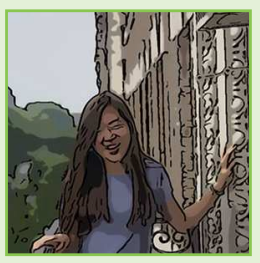

\section{JULIETTE, AGE: 15}

My name is Juliette and I am currently in my sophomore year. In addition to my interest in science and math, I love playing chess; I learned how to play at a young age, and have been competing ever since, usually on the weekends, which is really fun. I play different sports as well, such as fencing and crew. I also love acting! I like to do black box performances at my school.

\section{AUTHORS}

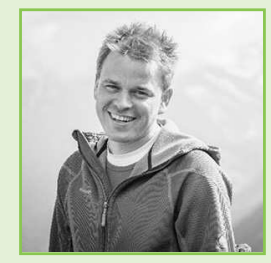

\section{JOHAN C. FAUST}

I am a marine geoscientist. My research focuses on how climate variability affects the Arctic environment. Specifically, I am investigating how changes in the Arctic Ocean sea ice cover and water mass distribution affect carbon burial in sediments from the Barents Sea. I graduated from the University Bremen, Germany and completed my Ph.D. at the Geological Survey of Norway/University of Troms $\varnothing$ in Norway. Since 2017, I am working in England at Leeds University. *j.faust@leeds.ac.uk

\section{CHRISTIAN MÄRZ}

A geologist by training and marine geochemist by choice, I have, over the last 10 years, studied the behavior of nutrients and metals in sediments of the Arctic Ocean and the North Pacific. My main focus is on the reconstruction of past environmental conditions from the archive of mud layers at the seafloor, and also 
on the transformation and recycling processes of chemical elements like iron, manganese, carbon, sulfur, phosphorus, and silica.

\section{SIAN F. HENLEY}

I am a marine biogeochemist with a passion for the polar oceans. I am fascinated by how nutrient and carbon cycles are changing in response to climate and environmental change, why these changes are important for ocean ecosystems, and the consequences of changes occurring in the oceans for Earth's climate system. I am lucky enough to work in Antarctica and the Arctic, with inspiring people and excellent facilities. Over the last 11 years, I have traveled over $17,000 \mathrm{~km}$ at sea on research ships and spent over 2 years in the magnificent polar regions, surrounded by incredible wildlife and awe-inspiring scenery. 